\title{
Publisher Correction: Clonal evolution of acute myeloid leukemia revealed by high-throughput single-cell genomics
}

Kiyomi Morita (D), Feng Wang, Katharina Jahn, Tianyuan Hu, Tomoyuki Tanaka, Yuya Sasaki, Jack Kuipers, Sanam Loghavi (B, Sa A. Wang, Yuanqing Yan, Ken Furudate, Jairo Matthews, Latasha Little, Curtis Gumbs, Jianhua Zhang (1), Xingzhi Song, Erika Thompson, Keyur P. Patel, Carlos E. Bueso-Ramos, Courtney D. DiNardo (1), Farhad Ravandi, Elias Jabbour, Michael Andreeff, Jorge Cortes (D), Kapil Bhalla, Guillermo Garcia-Manero (D), Hagop Kantarjian, Marina Konopleva (D), Daisuke Nakada (D), Nicholas Navin, Niko Beerenwinkel(D, P. Andrew Futreal (1) \& Koichi Takahashi (i)

Correction to: Nature Communications https://doi.org/10.1038/s41467-020-19119-8, published online 21 October 2020.

The original version of this Article contained an error in the author affiliations.

Daisuke Nakada was incorrectly associated with 'Department of Hematopathology, The University of Texas MD Anderson Cancer Center, Houston, TX, USA' instead of the correct 'Department of Molecular and Human Genetics, Baylor College of Medicine, Houston, TX, USA.'

This has now been corrected in both the PDF and HTML versions of the Article.

Published online: 19 November 2020

\footnotetext{
(c) Open Access This article is licensed under a Creative Commons Attribution 4.0 International License, which permits use, sharing, adaptation, distribution and reproduction in any medium or format, as long as you give appropriate credit to the original author(s) and the source, provide a link to the Creative Commons license, and indicate if changes were made. The images or other third party material in this article are included in the article's Creative Commons license, unless indicated otherwise in a credit line to the material. If material is not included in the article's Creative Commons license and your intended use is not permitted by statutory regulation or exceeds the permitted use, you will need to obtain permission directly from the copyright holder. To view a copy of this license, visit http://creativecommons.org/licenses/by/4.0/.
}

(C) The Author(s) 2020 